\title{
Ocular trauma in Mosul. Descriptive study
}

\author{
Amer Y. Rajab \\ From the Department of Surgery, College of Medicine, University of Mosul, Mosul, Iraq. \\ Correspondence: Amer Y. Rajab. ameryahya50@yahoo.com.
}

(Ann Coll Med Mosul 2013; 39 (2): 128-131).

Received: $3^{\text {th }}$ Jan. 2012; Accepted: $4^{\text {th }}$ Mar. 2013.

\section{ABSTRACT}

Objective: To determine the incidence of ocular trauma (OT) in Mosul.

Methods: Retrospective case series study of (156) patients of OT admitted to Al-Jamhori Teaching Hospital, who were referred from emergency department to ophthalmic unit during one year from $1^{\text {st }}$ Jan. till $31^{\text {st }}$ Dec. 2010. Data regarding age and sex of patients, and types, causes and season of injuries were noted.

Results: About $4.4 \%$ (156 out of 3307) of patients admitted to ophthalmic unit as (OT) in one year period and $4.3 \%$ of operations (101 out of 2335 ) done for OT in operative theater, $85.2 \%$ were males, and $89.1 \%$ were 30 years and younger. Mean age was 15.8 years \pm 13.2 SD, 60.3\% (94/156) were open-globe injuries and there were seasonal differences.

Conclusion: Young age males were mostly affected and open-globe injuries were the commonest types. Also there were seasonal differences.

$$
\begin{aligned}
& \text { الإصابات العينية في الموصل. دراسة توضيحية }
\end{aligned}
$$

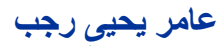

$$
\begin{aligned}
& \text { فرع الجراحة، كلية الطب، جامعة الموصل، الموصل، العراق }
\end{aligned}
$$

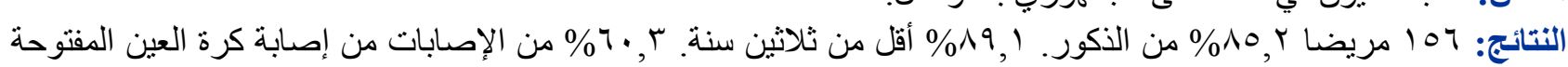

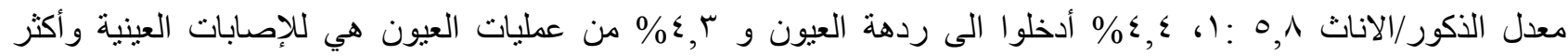

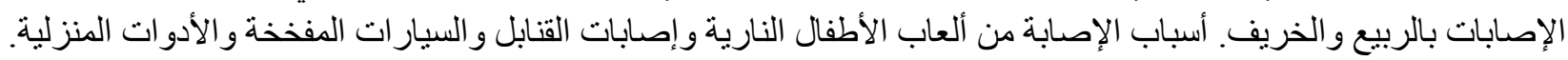
الإسنتتاج: حملة توعية الى الآباء والأمهات للإهتمام بالأطفال وطرق لعبهم. لأن أكثر الإصابات تحدثات الإت عند الأطفال الذكور وفي فصلي الربيع و الخريف.

\section{INTRODUCTION}

$\mathrm{O}$ cular trauma (OT) especially open-globe form, is the most common cause of monocular visual impairment and blindness worldwide, with significant socioeconomic impact. ${ }^{1,2}$ OT is an important, preventable worldwide public health problem. ${ }^{3}$ In the USA more than 40 thousands patients get permanent visual impairment. $^{4,5}$

Although it affects all age groups, previous studies had indicated that young males are mostly affected with the majority younger than 30 years. ${ }^{6}$
Incidence rate for hospitalized OT in developed world ranges from 8 per 100,000 in Scotland ${ }^{7}$ through 13 per 100,000 in United States, ${ }^{8}$ to 33 per 100,000 in Papua New Guinea. ${ }^{9}$

The situation is certainly worse in developing countries where the problem is compounded by general lack of access to preventive health care at all levels. When considering eyes injuries requiring hospital admission, rates had ranged from 8 to 57 per $100,000 .{ }^{10-15}$ Despite the heterogeneity of results, these studies provide important information regarding the burden of eye injury. 
The pattern of presentation of OT revealed a form of bimodal distribution over the one year period. There was a rise in cases between March and May tapering off in June and a second increase in September to November, tapering off in December, these patterns are especially so for the farmers and school-going children. ${ }^{16}$

Ocular trauma is classified by the standardized international classification of ocular trauma (Birmingham Eye Trauma Terminology BETT). ${ }^{17}$ Moreover the ocular trauma classification system (OTCS) ${ }^{18}$ classified the ocular trauma on basis of visual acuity, anatomical location of wound, mechanism of injury and presence of an afferent pupillary defect; also referred to ocular trauma score $(\mathrm{OTS})^{19}$ in evaluating the final visual outcome.

This study is aimed at providing an epidemiologic data on the current situation of ocular trauma in part of Mosul city based on hospital records, for the sake of planning and provision of eye care and safety strategies for prevention of such injuries in the region.

\section{PATIENTS AND METHODS}

Retrospective case series study involving a review of all cases of ocular injuries admitted to AlJamhori Teaching Hospital which were referred from emergency department to ophthalmic unit and the primary surgical intervention performed in ophthalmic theater under supervision of specialists, in one year period from $1^{\text {st }}$ Jan. till $31^{\text {st }}$ Dec. 2010.

Patients' information from the case sheet were retrieved and analyzed. Data regarding age and sex of patients, and types of injuries, cause and season of injuries were noted. In this study ocular trauma is defined as any injury affecting the eye or adnexa requiring hospital admission.

Ocular injuries were classified using the Birmingham Eye Trauma Terminology (BETT) ${ }^{17}$ system which is not depending on visual acuity. Box 1 shows definitions used in the BETT.

Box 1. Ocular trauma definitions.

\begin{tabular}{|c|c|}
\hline Lamellar laceration & Partial-thickness wound of eye wall \\
\hline Laceration & $\begin{array}{l}\text { Full-thickness wound of eye wall } \\
\text { caused by sharp object }\end{array}$ \\
\hline Rupture & $\begin{array}{l}\text { Full thickness wound of eye wall } \\
\text { caused by blunt object }\end{array}$ \\
\hline Penetration injury & Eye wall laceration with no exit wound \\
\hline Perforation injury & Eye wall laceration with exit wound \\
\hline
\end{tabular}

Patients with blunt force have contusion closed globe injury (CG injury) or rupture open globe injury (OG injury) and those with sharp forces have lamellar, laceration (CG injury) or penetrating, perforating and intraocular foreign body (IOFB), laceration (OG injury).

\section{RESULTS}

A total of 156 patients with OT were admitted to ophthalmic unit who were referred from emergency department during the study period. Sixty four point seven percent needed surgical intervention and the rest $(35.3 \%)$ were treated conservatively.

Ocular trauma cases represented $4.4 \%$ of the total admission to ophthalmic unit, $85.3 \%$ $(133 / 156)$ were males, with a male to female ratio of 5-6:1 as shown in Table 1.

The mean age was 15.8 \pm 13.2 SD (range from 6 months to 59 year), $89.1 \%$ of them were 30 years and younger and $62.2 \%(97 / 156)$ were children 16 year and younger as shown in Table 1.

Open globe OT were by far the most common types of injuries 48.7 (76/156), 39.7 (62/156) close globe OT, and $11.6(18 / 156)$ adnexal injuries, all cases were monocular as shown in Table 2. Sixty two point two percent of OT were caused by sharp, and $37.8 \%$ were due to blunt injuries.

Etiologically a wide range of objects were involved, these included children toys (used in Eid celebration), bomb, shells, exploded gun powder, twigs, pieces of wood, sharp sticks, pencils, catapult and brawls.

The clinical and surgical procedures performed were summarized in Table 3 . The most common primary surgery was reconstitution of the globe integrity with reposition or excision of ocular contents. All surgeries were performed within 12 hours of presentation to the hospital.

Table 1. Age-sex distribution of the cases of OT.

\begin{tabular}{lcrlllll}
\hline \multicolumn{1}{c}{ Age } & \multicolumn{1}{c}{ Male } & $\%$ & \multicolumn{2}{c}{ Female } & \multicolumn{2}{c}{ Total } & $\%$ \\
\hline $0-10$ & 51 & $32.7 \%$ & 20 & $12.8 \%$ & 71 & $45.5 \%$ \\
$11-20$ & 33 & $21.2 \%$ & 2 & $1.3 \%$ & 35 & $22.5 \%$ \\
$21-30$ & 32 & $20.5 \%$ & 1 & $0.6 \%$ & 33 & $21.1 \%$ \\
$31-40$ & 9 & $5.8 \%$ & 0 & 0 & 9 & $5.8 \%$ \\
$41-50$ & 2 & $1.3 \%$ & 0 & 0 & 2 & $1.3 \%$ \\
\hline $51-60$ & 6 & $3.8 \%$ & 0 & 0 & 6 & $3.8 \%$ \\
\hline Total & 133 & $85.3 \%$ & 23 & $4.7 \%$ & 156 & $100 \%$ \\
\hline
\end{tabular}


Table 2. Types of injury.

\begin{tabular}{|c|c|}
\hline Types of injury & Numbers \\
\hline Closed injury & 62 \\
\hline Lamellar laceration & 8 \\
\hline Contusion & 54 \\
\hline Contusion with corn FB & 28 \\
\hline Hyphema & 24 \\
\hline Lens dislocation & 0 \\
\hline Viterous Hemorrhage & 2 \\
\hline Open injury & 76 \\
\hline Laceration & 71 \\
\hline Penetrating injury limited to cornea & 10 \\
\hline $\begin{array}{l}\text { Penetrating corneal injury involving } \\
\text { lens or uvea or both }\end{array}$ & 40 \\
\hline $\begin{array}{l}\text { Penetrating corneal injury with or } \\
\text { without lens involvement }\end{array}$ & 10 \\
\hline Intraocular FB & 11 \\
\hline Globe rupture & 5 \\
\hline Adnexal injury* & 18 \\
\hline Total & 156 \\
\hline \multicolumn{2}{|l|}{ * Eyelids. } \\
\hline \multicolumn{2}{|l|}{$\begin{array}{l}\text { Table 3. Procedure employed for } \\
\text { hospitalized patients with OT. }\end{array}$} \\
\hline Procedure & $\begin{array}{l}\text { Percentage } \\
\text { (number) }\end{array}$ \\
\hline $\begin{array}{l}\text { Medical therapy and simple repair } \\
\text { of OT. (including primary repair of } \\
1 \text { eyelid, conjunctiva, cornea and } \\
\text { scleral wounds) and removal of FB } \\
\text { from cornea and AC. }\end{array}$ & $\begin{array}{c}51.3 \% \\
(80)\end{array}$ \\
\hline $\begin{array}{l}\text { Complex repair of ocular injuries } \\
\text { (including repair of large corneo- } \\
\text { scleral wound, excision of } \\
\text { prolapsed uveal tissue, removal of } \\
\text { lens, anterior vitrectomy. }\end{array}$ & $\begin{array}{c}38.5 \% \\
(60)\end{array}$ \\
\hline $\begin{array}{l}3 \text { Removal } 10 \text { FB from post chamber } \\
\text { and post segment by use of } \\
\text { magnet. }\end{array}$ & $\begin{array}{l}7 \% \\
(11)\end{array}$ \\
\hline \multirow[t]{2}{*}{$\begin{array}{l}\text { Enucleation of eye ball in rupture } \\
\text { globe, primary or secondary } \\
\text { enucleation. }\end{array}$} & $\begin{array}{l}3.2 \% \\
(5)\end{array}$ \\
\hline & $\begin{array}{l}100 \% \\
(156)\end{array}$ \\
\hline
\end{tabular}

The majority of primary repairs of open globe injuries were done by suturing of the wound with or without excision of prolapsed intraocular content or lensectomy (65.2\%) (60/92).

Four primary enculeations were performed for severely ruptured globes, and one needed secondary enculeation, all these injuries were caused by bomb or shell. Among the open globe injuries, lensectomy was performed in 5 cases (5.4\%) during primary repair and in 12 eyes with traumatic cataract; lens removal was deferred due to the state of the eye and technical difficulties.
Sixty two point two percent of the patients were school children (16 years and younger). The remaining $37.8 \%$ belonged to soldiers, policemen, farmer office workers, house wives and businessmen.

The pattern of presentation revealed a form of bimodal distribution over one year period; there was a rise in spring 42 patients $(26.9 \%)$ (March to May) and autumn 43 patients (27.6\%) (September to November) (Figure 1) which may be due to spring outings and Eid celebration (in Autumn). However, there was no statistical significance regarding different seasons.

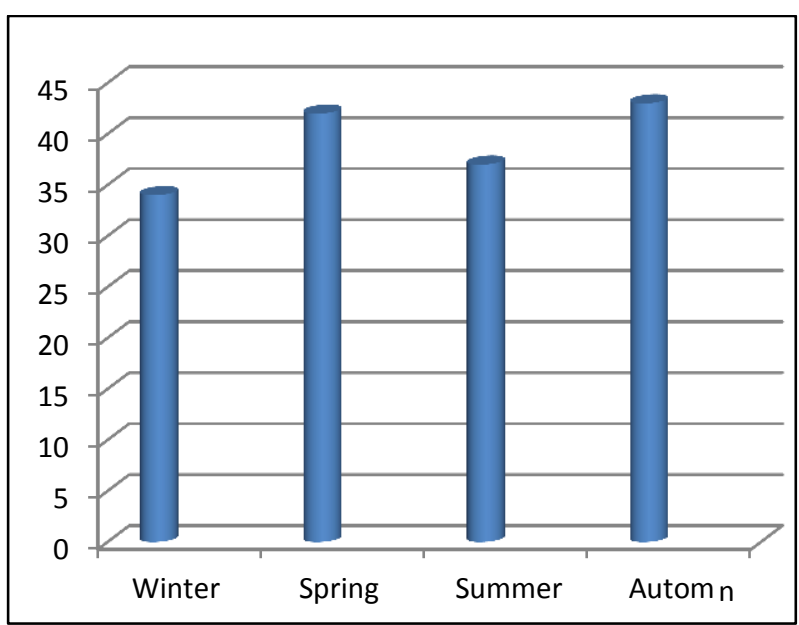

Figure 1. Distribution of OT patients during seasons of one year.

\section{DISCUSSION}

Ocular traumas are common and largely a preventable cause of monocular visual impairment and blindness. Hospital-based studies shows that $5 \%$ to $16 \%$ of all ophthalmic admissions to eye hospital/units are related to ocular trauma. ${ }^{20}$

The incidence of $4.4 \%$ found in our study is consistent with previous reports. The propensity toward young male and school-going children was consistent with those identified by others. Our results of $85.3 \%$ male and $89.1 \%$ aged younger than 30 years paralleled the trends reported by other authors. ${ }^{7,8,20,21}$

This pattern of distribution, with the majority of cases involving young and working groups, highlights the socio-economic burden of OT on our communities.

In most previous studies occupational injuries were reported to be the commonest cause of OT in adults. But in our study most of the OT occurred in children $(62.2 \%)$ which may be due to neglect and 
uses of harmful toys or games. In developing communities most of injuries occur in farming activities, while industrial activities in developed communities were responsible for the majority of cases. $^{8-11}$

The bimodal distribution over one year period in spring and autumn may be due to spring outings and Eid celebrations.

The lack of improvement in many of the cases due to our inability to manage some of the complications associated with OT, the lack of vitreo-retinal and corneal expertise, and equipment to manage these complications, might have contributed adversely and led the patients to seek medical advice outside Mosul city.

The presence of cataracts which were not operated upon due to reasons afore-mentioned may have contributed significantly to the poor outcome seen at discharge. In our setting, however, the problem is compounded by low review visits by patients following discharge from hospital.

\section{CONCLUSION}

1. Ocular traumas were more common in male children, and in Spring and Autumn seasons.

2. Open globe injuries were the commonest types of injuries.

\section{REFERENCES}

1. Negrel AD, Thylefors B. The global impact of eye injuries. Ophthalmic Epidemiol. 1998; 5:143-169.

2. Thylefors B. Epidemiological patterns of ocular trauma. Aust NZ J Ophthalmol. 1992;20:95-98.

3. Whitcher JP, Srinivasan M, Upadhyay MP. Corneal blindness: a global perspective. Bull World Health Organ. 2001;79:214-221.

4. McGwin G, Xie A, Owsley C. The rate of eye injury in the United States. Arch Ophthalmol. 2005;123:970-976.

5. Mieler W. Overview of ocular trauma. In: Albert D, Jakobiec $F$, editor. Principles and Practice of Ophthalmology. $2^{\text {nd }}$ ed. Philadelphia, WB Saunders Co; 2001. p. 5179.
6. Tielsch JM, Parvel L, Shankar B. Time trends in the incidence of hospitalized ocular trauma. Arch Ophthalmol. 1989;107:519-523.

7. Desai $P$, MacEwin CJ, Baines $P$, Minassian DC. Incidence of ocular trauma admitted to hospital and incidence of blinding outcome. $\mathrm{Br} J$ Ophthalmol. 1996;80:592-596.

8. Klopter J, Tielsch JM, Vitale S, et al. Ocular trauma in the United States. Arch Ophthalmol. 1992;110:838-842.

9. Verma N, Verma A, Jacob G, Demok S. Profile of ocular trauma in Papua New Guinea. Aust NZ J Ophthalmol. 1997;123:820-831.

10. Tielsch JM, Parver L, Shankar B. Time trends in the incidence of hospitalized ocular trauma. Arch Ophthalmol. 1989;107:519-523.

11. McCarty CA, Fu CL, Taylor HR. Epidemiology of ocular trauma in Australia. Ophthalmology. 1999;106:1847-1852.

12. Desai $P$, MacEwen CJ, Baines $P$, Minassian DC. Incidence of cases of ocular trauma admitted to hospital and incidence of blinding outcome. $\mathrm{Br} \mathrm{J}$ Ophthalmol. 1996;80:592-596.

13. Klopfer J, Tielsch JM, Vitale S, See LC, Canner JK. Ocular trauma in the United States: eye injuries resulting in hospitalization, 1984 through 1987. Arch Ophthalmol. 1992;110:838-842.

14. Karlson TA, Klein BE. The incidence of acute hospital-treated eye injuries. Arch Ophthalmol. 1986;104:1473-1476.

15. Wong TY, Tielsch JM. A population-based study on the incidence of severe ocular trauma in Singapore. Am J Ophthalmol. 1999;128:345-351.

16. Wong TY, Klein BE, Klein R. The prevalence and 5year incidence of ocular trauma. The Beaver Dam Eye Study. Ophthalmology. 2000;107:2196-2202.

17. Kuhn F, Morris F, Witherspoon CD, Mester V. The Birmingham Eye Trauma Terminology system (BETT) J FrOphtalmol. 2004;27:206-210.

18. Pieramici DJ, Sternberg $P$, Aaberg TM, et al. A system for classifying mechanical injuries of the eye (globe). The Ocular Trauma Classification Group. Am J Ophthalmol 1997;123:820-831.

19. Kuhn F, Maisiak R, Mann L, Mester V, Morris R, Witherspoon CD. The ocular trauma score (OTS) Ophthalmol Clin N Am 2002;15:163-165.

20. Tielsch JM, Parvel L, Shankar B. Time trends in the incidence of hospitalized ocular trauma. Arch Ophthalmol 1989;107:519-523.

21. Desai $P$, MacEwen CJ, Baines $P$, Minassian DC. Incidence of cases of ocular trauma admitted to hospital and incidence of blinding outcome. $\mathrm{Br} J$ Ophthalmol 1996;80:592-596. 